\title{
TOŻSAMOŚĆ NARODOWA ŻOŁNIERZY ARMII AUSTRO-WĘGIERSKIEJ
}

\author{
Michał Baczkowski \\ Uniwersytet Jagielloński w Krakowie
}

\section{ABSTRACT \\ NATIONAL IDENTITY OF AUSTRO-HUNGARIAN SOLDIERS}

In the Austrian army (Austro-Hungarian army) in the second half of the $19^{\text {th }}$ century the question of the national identity of officers and soldiers belonged to the most important problems of the Habsburg monarchy. Officially proclaimed army transnational password ("imperial"), in which the officers and soldiers of different nationalities and different faiths were fully-fledged and united by the idea of a common state, which was the personification of the emperor. The privileged role of the German language in the army had technical, not ideological reasons. In fact, by the second half of the $19^{\text {th }}$ and early $20^{\text {th }}$ century a dispute was waged among the generals and politicians on whether the army was to be transnational, multinational, or German.

In the context of transnational password Galician, the "imperial" army was popular especially among the peasant population. The "imperial" identification of the rural population was strengthened by the social conflict on the axis: noblemen (Polish) - peasants ("imperial"). Military service was associated with an increase in the standard of living by most of the recruits and with prestige in rural communities. These aspects further reinforced the "imperial" identity of the recruits. With the development of the modern sense of national consciousness in the late $19^{\text {th }}$ century this identity was modified in the case of the Polish. During World War I the "imperial" identity of the Galician recruits was eventually weakened by failures at the front, the economic crisis and the collapse of state authority. In 1918 it was only a historical memory.

Key words: Galicia, military, identity.

Słowa kluczowe: Galicja, wojsko, tożsamość.

Czy armia austro-węgierska była wielonarodowa czy też ponadnarodowa, a może wręcz niemiecka? Takie pytania nurtowały wielu habsburskich oficerów i żołnierzy w drugiej połowie XIX wieku, a następnie badaczy dziejów tejże monarchii. Wspomniana kwestia dotyczyła przede wszystkim samoświadomości korpusu oficerskiego 
oraz tożsamości szeregowych żołnierzy, odbywających służbę wojskową w ramach przymusowego poboru, jak również obowiązującego w armii kodeksu wartości ${ }^{1}$. Miała zarazem fundamentalne znaczenie zarówno dla dalszego funkcjonowania państwa, jak i kształtowania się nowoczesnej świadomości narodowej obywateli Austro-Węgier. W czasach odrodzenia narodowego wielu grup etnicznych, rozwijających się nacjonalizmów oraz rosnących konfliktów między poszczególnymi narodami monarchii sprawa tożsamości c.k. żołnierzy stawała się problemem ogólnopaństwowym. Ideowy kształt sił zbrojnych i ich funkcja w tworzeniu postaw świadomościowych miały ogromne znaczenie dla losów państwa.

Wojsko habsburskie, „cesarskie”, miało zawsze wielonarodowościowy i, w dużej mierze, kosmopolityczny charakter. Służyli w nim nie tylko poddani habsburscy z Austrii, Czech, Węgier czy Chorwacji, lecz także nader liczni cudzoziemcy, przede wszystkim Niemcy, w mniejszym stopniu Włosi, Szkoci, Irlandczycy, Francuzi, Polacy i przedstawiciele jeszcze innych grup etnicznych spoza monarchii habsburskiej. Kosmopolityczny charakter armii utrzymał się do końca wojen napoleońskich. Według wytycznych Nadwornej Rady Wojennej z 1777 roku w czasie pokoju co najmniej $60 \%$ chętnych do służby w armii habsburskiej miało być werbowanych spośród cudzoziemców. W praktyce sami Niemcy z Rzeszy stanowili około 30\% stanu osobowego całej armii habsburskiej ${ }^{2}$. Szczególnie licznie cudzoziemcy reprezentowani byli w korpusie oficerskim oraz wśród generalicji. Raimondo Montecuccoli, książę Eugeniusz Sabaudzki, Maximilian Browne, Johannes i Karl O’Donellowie, Franz Moritz Lacy, Ernst Gideon Laudon to tylko kilka przykładów habsburskich feldmarszałków obcej proweniencji. Ten kosmopolityczny charakter armii uległ wyraźnej zmianie po 1815 roku, kiedy to możliwości werbunku obcych poddanych radykalnie zmalały, a z cudzoziemców na służbę w wojsku habsburskim decydowali się głównie przedstawiciele niemieckich rodów panujących i arystokratycznych. Po wydarzeniach Wiosny Ludów do wojska przyjmowano już tylko własnych poddanych.

Od drugiej połowy XVIII wieku w Austrii toczyła się dyskusja, jaki charakter powinna mieć armia: czy cesarsko-niemiecki, czego zwolennikiem był feldmarszałek Franz Moritz von Lacy, czy też cesarsko-ponadnarodowy, do czego zdawała się dążyć większość generalicji i polityków3 ${ }^{3}$ Ta druga koncepcja wydawała się bardziej racjonalna, tradycjonalistyczna, dobrze ugruntowana w doświadczeniach wojskowych monarchii. Walory odwoływania się do ponadnarodowych wartości, czyli osoby cesarza oraz państwa rozumianego jako ogół wielojęzycznych poddanych Habsburgów, okazały się szczególnie istotne w okresie rewolucji i powstań narodowych. W tym przypadku ponadnarodowa, „cesarska” tożsamość oficerów i prostych żołnierzy stanowiła dodatkowy atut państwa, tworząc niewidzialną, ale wyraźną barierę między

Zob. szerzej: J.Ch. Allmayer-Beck, Die bewaffnete Macht in Staat und Gesellschaft [w:] Die Habsburgermonarchie 1848-1918, Bd. 5: Die bewaffnete Macht, Hg. A. Wandruszka, P. Urbanitsch, Wien 1987; J.Ch. Allmayer-Beck, E. Lessing, Die k. (u.) k. Armee 1848-1918, Wien 1974; I. Deák, Der k. (u.) k. Offizier, Wien 1991.

2 A. von Wrede, Geschichte der k. und k. Wehrmacht, Bd. 1, Wien 1898, s. 102.

3 E. Kotasek, Graf Lacy. Ein Leben für Österreichs Heer, Horn 1956, s. 122-123; Österreichisches Staatsarchiv/Kriegsarchiv w Wiedniu (dalej: KA), Kriegsminister Lacy Akten (dalej: KLA) 1774, nr 5/1. 
światem cywilnym, podatnym na różnorakie hasła polityczne i narodowe, a wojskiem stającym poza i ponad tymi problemami. Podczas interwencji zbrojnych na Półwyspie Apenińskim w latach 1820-1821 i 1831, a przede wszystkim podczas konfliktów wewnętrznych w latach 1846 i 1848-1849 armia w swojej masie zachowała lojalność wobec monarchy. „W Twoim obozie jest Austria”, głosił Franz Grillparzer w odzie skierowanej do feldmarszałka Josefa Wenzela Radetzky'ego podczas Wiosny Ludów, wychwalając zarazem ponadnarodową solidarność żołnierzy różnych narodowości, stających razem do walki pod sztandarem Habsburgów

W połowie XIX wieku idea ponadnarodowej armii habsburskiej nie tylko była zatem powszechnie akceptowana przez korpus oficerski oraz znaczną część rekrutów, ale też uzyskała swój literacki wyraz. Po Wiośnie Ludów tekst Grillparzera stał się półoficjalną dewizą wojsk habsburskich, powielaną we wszelkich możliwych pracach poświęconych armii, jej historii, teraźniejszości oraz zadaniom na przyszłość. Stopniowo funkcja wojska jako głównej ponadnarodowej siły spajającej monarchię miała jeszcze wzrosnąć. Tak przynajmniej w 1886 roku głosił arcyksiążę Albrecht, czołowy bohater i ideolog wojsk austriackich (austro-węgierskich) drugiej połowy XIX wiekus.

Szerokie, a zarazem bliżej niesprecyzowane zadania ideowe stawiane armii musiały prowadzić do wielu problemów. Przede wszystkim spowodowały po 1848 roku coraz silniejszą alienację korpusu oficerskiego ze świata cywilnego. Głoszone przezeń wartości stawały się coraz mniej atrakcyjne dla środowisk ziemiańskich, burżuazyjnych i inteligenckich. Odwoływały się do przebrzmiałego kodeksu wartości szlachty monarchii naddunajskiej z minionej epoki, gdy problem nowocześnie rozumianej świadomości narodowej jeszcze nie odgrywał większej roli, a patriotyzm postrzegano jako lojalność względem władcy i własnego kraju koronnego. Po 1848 roku idee te sprowadzały się do kultu osoby Franciszka Józefa I oraz swoiście pojmowanej idei wspólnoty „,esarskiej”, której armia miała być nosicielem i najlojalniejszym obrońcą. Korpus oficerski, zasklepiony w sobie i świadomie separujący się od świata cywilnego, funkcjonujący często we wrogim otoczeniu, potrzebował jak nigdy wzmocnienia własnej tożsamości. Jedyną wspólną płaszczyzną ideową dla tych ludzi, wywodzących się z różnych grup etnicznych i społecznych, pozostała świadomie kultywowana tożsamość „,cesarska”.

W pierwszej połowie XIX stulecia idea „cesarska” była stosunkowo nośna i popularna wśród szerokich kręgów ludności cywilnej, przede wszystkim chłopstwa, części

${ }^{4}$ Najpełniej ideę ponadnarodowej armii habsburskiej wyraził Franz Grillparzer w siódmej zwrotce swojej ody Feldmarschall Radetzky:

„Die Gott als Slav und Magyaren schuf,

Sie streiten um Worte nicht hämisch,

Sie folgen, ob deutsch auch der Feldherrnruf,

Denn: Vorwärts! ist ungrisch und böhmisch".

Cyt. za: F. Grillparzer, Sämtliche Werke, Bd. 1, München 1960, s. 318-319.

5 J.Ch. Allmayer-Beck, op. cit., s. 94-96.

6 J. Ryde1, W stużbie cesarza i króla. Generałowie i admirałowie narodowości polskiej w siłach zbrojnych Austro-Węgier w latach 1868-1918, Kraków 2001, s. 110-111; J.Ch. Allmayer-Beck, op. cit., s. 37-39. 
aparatu urzędniczego oraz coraz mniejszego odsetka szlachty. Tworzyła dość spójny obraz świata oraz państwa, w którym przyszło żyć wielojęzycznym poddanym. Ich głównym i niejako jedynym łącznikiem, obrońcą i prawodawcą, „ojcem ojczyzny” pozostawał cesarz. Czuwając nad dobrem swoich poddanych, ograniczał ewentualne napięcia na tle narodowym oraz religijnym w imię dobra wspólnego, państwowego. Po wojnach napoleońskich bardzo sprymitywizowana idea cesarska zdobyła znaczną popularność wśród chłopstwa galicyjskiego. Wiązała się przede wszystkim z konfliktem społecznym na linii chłopstwo-ziemiaństwo, w którym cesarz zaczął być postrzegany jako obrońca interesów chłopskich. Nie wchodząc w szczegóły ani powody sukcesu takiego sposobu postrzegania rzeczywistości, należy stwierdzić, że dotyczyła ona kwestii socjalno-ekonomicznych, a nie narodowościowych czy ogólnopaństwowych. Galicyjski żołnierz, podobnie jak galicyjski chłop, najczęściej określał się jako „cesarski”. Pod tym pojęciem należało rozumieć negację tożsamości polskiej, utożsamianej z „panami”, czyli szlachtą, ale także z duchowieństwem oraz mieszczaństwem. Był to zewnętrzny wyraz animozji i konfliktu „sukmany” z „surdutem", chłopów z niechłopami, który w decydujący sposób przyczyniał się do kształtowania się wiejskiej samoświadomości. Jej dalekosiężnym następstwem mogło być uznanie się także pod względem ideowym za „cesarskiego”, względnie „Galicjanina" w opozycji do świadomego Polaka (Ukraińca) ${ }^{7}$. O tym problemie pisali między innymi Seweryn Goszczyński oraz polscy konspiratorzy lat 30. i 40. XIX wieku Zwulgaryzowana „cesarskość” stała się wówczas jednym z głównych składników tożsamości chłopskiej. Idea ta szła w lud z dwóch kierunków: militarnego, związanego z długotrwałą służbą wojskową tysięcy galicyjskich rekrutów, oraz cywilnego, będącego rezultatem antyszlacheckiej postawy i propagandy wielu lokalnych urzędników, nakładającej się na realne problemy społeczne?

Spektakularnym triumfem tej postawy w Galicji były wydarzenia 1846 roku, czyli zdławienie powstania krakowskiego oraz rozpętanie rabacji, podczas których chłopi (w dużym stopniu urlopnicy z armii austriackiej) demonstracyjnie głosili swoją bliżej niesprecyzowaną „,esarską” tożsamość ${ }^{10}$. Można wszakże powątpiewać, na

7 Nie podejmuję tu kwestii służby wojskowej Żydów galicyjskich. Wysuwane w literaturze niemieckojęzycznej tezy o przyjęciu przez Żydów z monarchii naddunajskiej, służących w c. k. armii, orientacji „cesarskiej” i utożsamieniu ideowym z państwem dotyczą raczej niemieckojęzycznych wyznawców judaizmu spoza Galicji. Szerzej na ten temat (wraz z wykazem ważniejszej literatury): M. B aczkowski, In Treue zu Kaiser und Vaterland - Galizische Juden im Militär der Habsburger, „Jahrbuch des SimonDubnow-Instituts" XII, 2013, s. 127-149.

8 Zob. [S. Goszczyński], Seweryn Goszczyński w Galicji. Nieznane pamiętniki, listy i utwory, 1832-1842, wyd. Z. Wasilewski, Lwów 1910.

9 O założeniach polityki austriackiej w kwestii chłopskiej w Galicji, zob. S. Grodziski, Historia ustroju społeczno-gospodarczego Galicji 1772-1848, Wrocław 1971, s. 65-88.

10 Szerzej zob: Rewolucja czy praca organiczna...; M. Żychowski, Rok 1846 w Rzeczypospolitej Krakowskiej i Galicji, Warszawa 1956, s. 180; S. Kieniewicz, Konspiracje galicyjskie (1831-1845), Warszawa 1950, s. 190-191; J. Louis-Wawel, Kronika Rewolucji Krakowskiej w roku 1846, Kraków 1898, s. 49-50, 69-70; F. Wiesiołowski, Pamiętnik z r. 1845-1846, Lwów 1868, s. 31; R. Janota, Geschichte des k. und k. Infanterie Regiments Graf Daun Nr. 56, Teschen 1889, s. 219; Geschichte des k. und k. Infanterie-Regiments Erzherzog Ludwig Salvator Nr. 58, Wien 1904, s. 160; KA, Alte Feldakten (dalej: AFA) Galizien 1846, karton 1805, raporty ze stycznia 1846. 
ile były to szczere deklaracje, a na ile wykalkulowane wypowiedzi, mające na celu jedynie zdobycie przychylności urzędników i wojskowych w trakcie dokonywanych grabieży i mordów.

Także w czasie Wiosny Ludów galicyjscy rekruci nie utożsamiali się z polskimi (względnie ukraińskimi) dążeniami narodowymi i wolnościowymi, ale zachowali pełną lojalność wobec cesarza, która w wielu wypadkach nabierała charakteru bezwzględnej rozprawy ze wszystkimi prawdziwymi czy też wyimaginowanymi wrogami państwa. Ekscesy te były najbardziej głośne w głównych ośrodkach polskiego ruchu narodowego: w Krakowie i we Lwowie ${ }^{11}$.

Wydarzenia lat 1846-1849 przyczyniły się do zmitologizowania postaw galicyjskich żołnierzy, na ogół pochodzenia chłopskiego, jako „cesarskich” patriotów. Tezy takie głosiła część korpusu oficerskiego na użytek propagandowy ${ }^{12}$. Rzeczywistość była o wiele bardziej skomplikowana. Armia austriacka celowo kreowała tożsamość „cesarską" swoich oficerów i rekrutów. Część z nich wszakże trafiała do wojska już jako ukształtowani „cesarscy”. Należeli do nich między innymi synowie zawodowych oficerów i wysłużonych podoficerów, a także niektórzy wiejscy poborowi. W ich przypadku służba wojskowa przyczyniała się do wzmocnienia i ugruntowania postaw wyniesionych jeszcze z cywila. Dziedziczenie zawodu oficera (lub podoficera) stawało się jednym z ważniejszych czynników wpływających na tożsamość armii ${ }^{13}$.

W tym miejscu należy poruszyć jeszcze jeden problem. Otóż można było postulować i propagować wojsko jako byt ponadnarodowy, złączony niemal w mistyczny sposób z ideą monarchii i samym cesarzem, nie sposób było jednak zanegować niemieckojęzycznego charakteru tej instytucji. Oficerowie i żołnierze, uznający się za „cesarskich”, podczas pełnienia służby używali komend w języku niemieckim, w tym języku tworzono całą dokumentację i terminologię wojskową, wreszcie to właśnie nim mieli się posługiwać oficerowie także w stosunkach pozasłużbowych w swoim kręgu ${ }^{14}$. Jednym słowem uprzywilejowanie, a w praktyce bezwzględna dominacja języka niemieckiego w armii stanowiła fakt oczywisty i niezaprzeczalny. Jak to się miało do idei ponadnarodowej, ,cesarskiej” armii?

Władze wojskowe dostrzegały ten problem. Usiłowano go zbagatelizować poprzez propagowanie tezy, że uprzywilejowanie języka niemieckiego w armii wynikało tylko z przyczyn technicznych. Był to język monarchy - zwierzchnika sił zbrojnych, instytucji rządowych, w tym ministerstwa wojny, przeważającej części

11 W. Prochazká, Geschichte des k. k. Infanterie Regimentes FML Wilhelm Freiherr von Rheinländer Nr. 24, Wien 1886, s. 451, 472-473; E. Kozłowski, Legion Polski na Wegrzech 1848-1849, Warszawa 1983, s. 51-52.

12 Szczególnie często podkreślano ten aspekt w oficjalnych monografiach poszczególnych pułków piechoty i kawalerii armii habsburskiej. Większość z nich wyszła drukiem w 1. 1870-1900 i miała za zadanie m.in. propagowanie postaw ponadnarodowych i ,cesarskich” wśród oficerów, podoficerów, a także szeregowców i weteranów wojsk austro-węgierskich.

13 J. Rydel, op. cit., s. 118-119, 165-168; M. von Auffenberg-Komarów, Aus Österreich-Ungarns Teilnahme am Weltkriege, Berlin-Wien 1920, s. 132-133.

14 J. Rydel, op. cit., s. 168. 
oficerów oraz najliczniejszej grupy etnicznej w monarchii ${ }^{15}$. Argumentacja ta w jakimś stopniu wydawała się zasadna w okresie przedkonstytucyjnym, ale po uchwaleniu zasad konstytucji grudniowej w 1867 roku i przeprowadzeniu reformy wojskowej rok później coraz powszechniej ją kwestionowano ${ }^{16}$.

Konstytucja grudniowa, wprowadzająca zasadę równouprawnienia narodów i języków w Austrii oraz gwarantująca każdej grupie etnicznej prawo zachowania swojej kultury i odrębności, zadawała poważny cios idei „cesarskiej” armii ponadnarodowej i przyczyniła się do ukształtowania wizji armii wielonarodowej o bardziej obywatelskim charakterze. W rzeczywistości wspomniane zapisy nie znalazły zastosowania w strukturach wojskowych (na zasadzie wyjątku), lecz w poważny sposób wpłynęły na zdynamizowanie procesów narodowościowych w Przedlitawii, w tym także w Galicji.

Większym ciosem dla idei i budowania tożsamości „cesarskiej” były jednak zapisy ustawy wojskowej z 1868 roku. Wprowadzała ona, a w rzeczywistości sankcjonowała istniejący już od dwóch lat powszechny obowiązek służby wojskowej w wymiarze trzech lat w linii lub też kierowała poborowego do przeszkolenia w ramach kadrowej Obrony Krajowej (Landwehry), względnie do Rezerwy Uzupełniającej (bez przeszkolenia). Reforma oznaczała zasadniczą zmianę w funkcjonowaniu armii. Wcześniej, to znaczy w pierwszej połowie XIX wieku, czas trwania służby wojskowej został oznaczony, w myśl zasad z lat 1802-1811, na 14 lat. W 1845 roku skrócono go do 8 lat. Wieloletnia służba prowadziła do wyobcowania poborowych ze społeczności cywilnej, silnego związania z macierzystym pułkiem, poznania podstaw języka niemieckiego oraz wyrobienia przekonania o potędze państwa. Przyczyniała się również do zaszczepienia szeregowym „cesarskiej” tożsamości. To właśnie z tych kręgów rekrutowali się obrońcy habsburskiego porządku podczas powstania krakowskiego w 1846 roku czy Wiosny Ludów. Reforma ograniczająca czas służby do trzech lat lub też do krótkiego przeszkolenia bardzo niekorzystnie wpływała na kształtowanie „cesarskiej” tożsamości rekrutów, tym bardziej że większość z nich nie znała języka niemieckiego i nie miała większych szans na opanowanie go w trakcie odbywania służby. Kwestię językową rozwiązano poprzez wprowadzenie tak zwanych języków pułkowych, w których miano nauczać szeregowców. Stały się nimi wszystkie uznane języki w państwie, przy zastrzeżeniu, że grupa żołnierzy

15 Österreich-Ungarns letzter Krieg 1914-1918, Hrsg. E. Glaise-Horstenau, Bd. 1, Wien 1930, s. 37; szerzej zob.: F. von Purschka, Rückblicke auf die Entwicklung des k. und k. österreichischen Heeres, Lemberg 1892; G. Rothenberg, The Army of Francis Joseph, West Lafayette 1998; A. Schmidt-Brentano, Die Armee in Österreich. Militär, Staat und Gesellschaft 1848-1867, Boppard am Rhein 1975; K. G1ückmann, Das Heerwesen der österreichisch-ungarischen Monarchie, Wien 1911; A. Danzer, Unter der Fahnen. Die Völker Österreich-Ungarns in Waffen, Wien 1889.

${ }_{16}$ O reformie wojskowej, zob. S. Szuro, Reforma wojskowa przeprowadzona w państwie austro-węgierskim w 1868 r. i jej realizacja ze szczególnym uwzględnieniem Galicji, „Studia i Materiały do Historii Wojskowości” 1990, t. 33, 1990. O zasadach konstytucji grudniowej, zob. Historia państwa i prawa Polski, t. 4: Od uwłaszczenia do odrodzenia Państwa, red. K. Grzybowski, Warszawa 1982. 
posługujących się danym językiem musi stanowić co najmniej 20\% (właściwie 19,7\%) całości stanu osobowego pułku ${ }^{17}$.

W oficjalnych statystykach wojskowych wszyscy poborowi po 1868 roku przypisani zostali do konkretnego języka, a w ślad za tym do odpowiedniej narodowości. Galicyjscy wojskowi mogli się określić jako Polacy, Ukraińcy lub Niemcy. Był to poważny cios w ponadnarodową ideę tożsamości „,cesarskiej” w armii, chociaż początkowo nie wywarł aż tak wielkiego wpływu na kwestię tożsamości wojska. Oznaczał on w dużym stopniu wyrugowanie języka niemieckiego na rzecz języków ojczystych poszczególnych grup rekrutów. Dopóki kwestia językowa nie przekładała się automatycznie na kontrowersje na tle narodowościowym, sprawa ta nie miała w armii większego znaczenia. Dopiero pod koniec XIX wieku, wraz ze stopniowym wzrostem nowocześnie rozumianego poczucia świadomości narodowej wśród rekrutów, obowiązujące normy prawne zaczęły sprzyjać działaniom na rzecz dekompozycji wojska i demonstrowaniu przez żołnierzy swojej narodowości ${ }^{18}$.

Głównym rzecznikiem „,cesarskiej” idei ponadnarodowej po 1867 roku pozostał zawodowy korpus oficerski, wspierany w swoich poczynaniach przez niektórych arcyksiążąt, a w wyjątkowych sytuacjach przez samego cesarza. Ignacy Daszyński, wrogo ustosunkowany do wojska, tak oceniał sytuację około 1900 roku:

Z wyjątkiem Niemców żaden naród nie uważał armii za swoją, tolerowano ją dość niechętnie. [...] Korpus oficerski, mający wyłącznie ideę dynastyczną „Najwyższego Pana Wojny”, patrzył z pogardą i nienawiścią na jakiekolwiek objawy narodowego patriotyzmu ${ }^{19}$.

Problem samoidentyfikacji dotyczył, rzecz jasna, także oficerów i żołnierzy z samej Galicji. Problemy świadomościowe Galicjan służących w c.k. armii są widoczne w stosunkowo nielicznych pamiętnikach oraz w niektórych wojskowych materiałach źródłowych (głównie o charakterze sądowym i personalnym). Wyłaniający się z nich obraz pozwala uchwycić pewne postawy i trendy, ale nie daje odpowiedzi, na ile były one reprezentatywne. Badania Jana Rydla potwierdziły istnienie grupy generałów austro-węgierskich pochodzenia polskiego, którzy ulegli wynarodowieniu i mimo zachowania polskobrzmiących nazwisk oraz świadomości swoich korzeni zatracili związki z polskością. Można jedynie spekulować, że wskutek wieloletniej służby wojskowej (często „dziedziczonej” po ojcu) i stałych kontaktów z innymi oficerami nabrali tożsamości „cesarskiej” oraz związali się z niemieckim obszarem kulturowym. Nie oznaczało to jeszcze nabycia niemieckiej świadomości narodowej i niemieckiego patriotyzmu ${ }^{20}$. Na łamach polskich pamiętników niemal zawsze odnotowywano przypadki aktywności „cesarskich” oficerów i podoficerów bardzo różnej proweniencji. Dominował wśród nich element niemiecko-czeski, ale trafiali się także Galicjanie pochodzenia polskiego lub ukraińskiego (ruskiego). Na ogół z niechę-

17 Dane na temat języków pułkowych oraz narodowości (w sensie etnicznym) poborowych zostały zamieszczone na łamach „Militär-Statistisches Jahrbuch” 1873-1911.

18 O problemach językowych w armii zob.: KA, Ministerium für Landesverteidigung (dalej: MLV), Präsidialakten, Sprachen 1908-1914, karton nr 967.

19 I. Daszyński, Pamiętniki, t. 1, Warszawa 1957, s. 193.

20 J. Rydel, op. cit., s. 165-168, 178-179. 
cią lub pogardą odnosili się do narodowych aspiracji szeregowców i ochotników jednorocznych. Ich świat wartości koncentrował się wokół osoby cesarza oraz armii będącej emanacją jego władzy, a zarazem odrębną strukturą administracyjną, wręcz quasi-państwową, oraz zastępczym domem ${ }^{21}$.

Dla wielu Galicjan pochodzenia chłopskiego „cesarska” tożsamość była w jakimś stopniu pochodną kwestii socjalnych i prestiżowych, związanych ze służbą wojskową. Mechanizm ten opisywali między innymi Wincenty Witos i Jakub Bojko, a znajduje on potwierdzenie w opracowaniach i materiale archiwalnym różnej proweniencji. Można wręcz zaryzykować tezę, że tożsamość tę budowała miska strawy, na którą wszakże składało się dziennie 190 gramów mięsa, 140 gramów jarzyn, 840 gramów chleba, porcja kawy oraz zupy. Wojskowa racja żywnościowa była bez porównania bogatsza od wyżywienia typowego dla wsi galicyjskiej. Do tego należy dodać sort mundurowy, bieliznę, dwie pary butów, tworzące ekwipunek żołnierski. Ponadto szeregowiec otrzymywał żołd w wysokości 58 koron rocznie, za który mógł nabyć tytoń i alkohol ${ }^{22}$. Nawet warunki kwaterowe, powszechnie krytykowane przez oficerów i polityków, były dla przeciętnego Galicjanina ze wsi lub małego miasteczka w pełni akceptowalne, a na ogół stwarzały o wiele wyższy komfort niż ten, który zapewniała rodzinna chałupa. To właśnie warunki materialne, umożliwiające egzystencję na wyższym poziomie niż w życiu cywilnym, w połączeniu ze swoistą dumą i poczuciem wyższości wobec nieżołnierzy, $w$ istotnym stopniu wpływały na prestiż armii i wzmagały postawy propaństwowe poborowych. Przysłowiowy „zupak”, dla którego świat zaczynał się i kończył w macierzystym regimencie, stawał się najlepszym nośnikiem tożsamości „cesarskiej”.

Służba wojskowa pociągała także ze względu na ambicję osobistą, a może jeszcze więcej honor, jaki dawało wojsko. Było ono bowiem między chłopami uważane za najważniejszą i najwięcej dostojną, uprzywilejowaną klasę, z którą się nawet szlachcice równać nie mogli, bo i oni byli „przebierani”, jeżeli się chcieli do wojska dostać. Wojskowego uważano też za więcej wartościowego od każdego, choćby najmądrzejszego cywila. Z większym jeszcze respektem odnoszono się do żołnierza, który służył przy ułanach albo też dobił się jakiejś szarży przy wojsku. Gwiazdki na kołnierzu miały niesłychane znaczenie, a ich właściciel był uważany za dostojnika całą gębą. Mundur wojskowy, buty z ostrogami, świecące guziki zawracały też głowę dziewczętom, które szalały za żołnierzami, nazywając „ufermami” tych, co nie byli przy wojsku. Niejednemu też z tych żołnierzy przyniosło to dobry ożenek, o którym w innych warunkach nie śmiałby marzyć. [...] Że służba w wojsku austriackim była ogromnie popularna, świadczyły też różne piosenki na ten temat szeroko znane i niemal przez wszystkich śpiewane. Oczywista, że one dotyczyły przeważnie cesarza, opiewając jego wielkość i dobroć, doli żoł-

${ }_{21}$ Zob. J. Bojko, Dwie dusze, Warszawa 1949; J. Haller, Pamiętniki, Londyn 1964; W. Kossak, Wspomnienia, Warszawa 1973; H. Liebermann, Pamiętniki, Warszawa 1996; S. Łańcucki, Wspomnienia, Warszawa 1957; M. Orłowicz, Moje wspomnienia turystyczne, Wrocław 1970; J. Romer, Pamiętniki, Lwów 1938; W. Witos, Moje wspomnienia, Olsztyn 1981; R. Żaba, Wspomnienia z lat ubiegłych, Kraków 2009; KA, Militärische Nachlässe (dalej: NL), B/608, cz. IV (Rudolf Biedermann); B/691 (Emil Ratzenhofer); B/862, cz. I (Adolf Stillfried).

22 W. Wagner, Die k. u. k. Armee - Gliederung und Aufgabestellung [w:] Die Habsburgermonarchie 1848-1918, Bd. 5: Die bewaffnete Macht, Wien 1987, s. 597; J.S. Bystroń, Kultura ludowa, Warszawa 1947, s. 68, 325-329. 
nierza, bohaterskich czynów armii, mądrości jej zwierzchników, których się niesłychanie bano, ale też szanowano, a nawet wielbiono ${ }^{23}$.

Do momentu nabycia nowoczesnej świadomości narodowej przez chłopów, co na masową skalę nastąpiło dopiero pod koniec XIX wieku, służba wojskowa sprzyjała szerzeniu się zwulgaryzowanej tożsamości „cesarskiej”. Od przełomu stuleci rola armii w tym zakresie zaczęła gwałtownie spadać. Wraz z rozwojem oświaty, powstaniem nowoczesnych partii politycznych, demokratyzacją państwa wśród rekrutów czeskich, następnie także ukraińskich i polskich, coraz większą rolę zaczęły odgrywać poglądy narodowe, a trzy- lub dwuletnia służba wojskowa nie była już w stanie zahamować tego procesu. Mimo wszystko konflikty narodowościowe, tak typowe dla wielu obszarów monarchii habsburskiej, zazwyczaj (choć nie zawsze!) kończyły się na progu koszar.

To żołnierskie zaś międzynarodowe zbiorowisko, mimo różnic głębokich, było ze sobą zżyte i niezwykle solidarne. Poza służbą żołnierze porozumiewali się mową swoją własną, będącą mieszaniną wszystkich języków ${ }^{24}$.

Czasami doświadczenia służby wojskowej prowadziły wręcz do prób demonstracyjnego porzucenia ojczystego języka przez galicyjskich rezerwistów.

[Żołnierz] po wysłużeniu w wojsku mówił źle po polsku, a niektórzy udawali, że nie umieją nic po polsku i bałamucili coś z niemiecka, coś z czeska, słowem językami wszystkich ludów austriackich, a tylko nie mówili swoim własnym językiem².

Postawy takie, typowe dla początku drugiej połowy XIX wieku, traciły stopniowo na atrakcyjności. Według Franciszka Bujaka:

Lud nasz w latach osiemdziesiątych nie miał jeszcze pojęcia o państwie, do którego należy, ani o swej ojczyźnie, której służyć powinien. Poglądy narodowe i polityczne mniej więcej były następujące: Galicja pozostaje pod władzą najbogatszego na świecie człowieka, cesarza, który dba o dobro swoich poddanych i chętnie by ulżył biedzie chłopskiej, gdyby panowie, siedzący po urzędach na prowincji i we Lwowie, chcieli mu przedstawić chłopską dolę ${ }^{26}$.

Opis ten charakteryzował uproszczoną wizję tożsamości „,esarskiej”, typową dla galicyjskiego chłopa i galicyjskiego rekruta w końcowej fazie istnienia jej funkcjonowania. W kolejnych latach nastąpiły zasadnicze przemiany świadomościowe na wsi galicyjskiej, które zadały idei cesarskiej decydujący cios.

Warto zwrócić uwagę na jeszcze jedną sprawę. W połowie XIX wieku galicyjscy poborowi odbywali służbę wojskową najczęściej poza Galicją, w miastach północnych Włoch, Węgier, czy wreszcie w Wiedniu lub w Czechach ${ }^{27}$. Na tych obszarach nie mieli szans na bliższe kontakty z ludnością cywilną, byli traktowani często jak okupanci, obcy pod względem językowym i kulturowym. Taki sposób dyslokacji

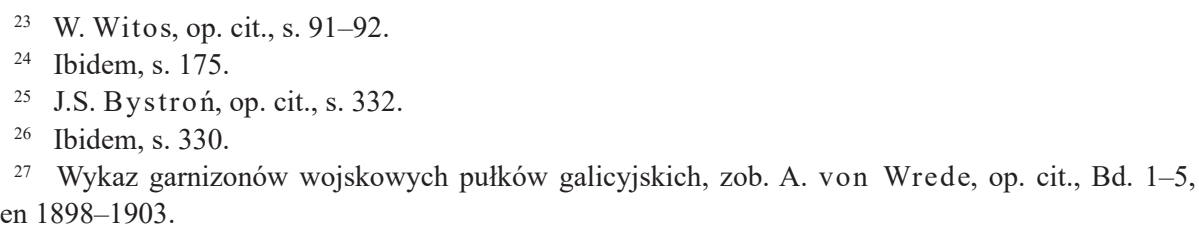
Wien 1898-1903. 
oddziałów liniowych sprzyjał izolowaniu wojskowych od świata zewnętrznego, wpojeniu żołnierzom nie tylko podstaw idei państwowej, lecz także pogardy wobec cywilów oraz wzmocnieniu ich „,esarskiej” tożsamości. W latach 70. i 80. XIX wieku sytuacja się jednak znacząco zmieniła. Pułki rozlokowano w większości w pobliżu własnych okręgów uzupełnień. Rekruci galicyjscy pełnili teraz służbę wojskową w Krakowie, Przemyślu, Lwowie oraz w mniejszych miastach Galicji. Bariera językowa i kulturowa w kontaktach z ludnością cywilną powoli traciła na znaczeniu. Pozostał konflikt na osi wieś-miasto, wojsko-cywile, ale on też tracił na ostrości ${ }^{28}$. Pobyt polskich szeregowych $\mathrm{w}$ garnizonach galicyjskich przyczyniał się $\mathrm{w}$ wielu przypadkach do wzmocnienia ich poczucia polskości, a przynajmniej osłabiał orientację „,cesarską".

W rozważaniach dotyczących „cesarskiej” tożsamości habsburskich wojskowych należy zwrócić uwagę na jeszcze jedną kwestię. Dla wielu oficerów zawodowych i podoficerów zawodowych (nadterminowych) wybór tejże samoidentyfikacji miał charakter stały i ostateczny. „Cesarskim” oficerem (podoficerem) zostawało się w wielu przypadkach na całe życie (przynajmniej do 1918 r.). Dla poborowego „cesarski” epizod tożsamościowy mógł mieć charakter czasowy i trwać kilka lat. Po zakończeniu służby wojskowej wielu rezerwistów nabierało nowej, narodowej identyfikacji, pod wpływem swojego otoczenia, lektury, udziału w życiu politycznym itp. Jednym słowem tożsamość „,cesarska” wojskowych mogła mieć charakter ostateczny, ale dla wielu młodych mężczyzn stanowiła tylko przejściowy epizod.

W chwili wybuchu I wojny światowej tożsamość „,cesarska” wojskowych była już w pełnym odwrocie. Dotyczyć mogła części zawodowego korpusu oficerskiego i podoficerskiego oraz wciąż topniejącej grupy poborowych. Czynnikiem osłabiającym ją okazał się zwłaszcza rozwój idei wielkoniemieckich wśród Niemców austriackich, którzy nieśli je ze sobą także do armii ${ }^{29}$. Ówczesna prasa galicyjska zaczęła wychwytywać i nagłaśniać wszelkie przejawy niemieckiego nacjonalizmu, czy wręcz szowinizmu w wojsku, wymierzonego w Polaków ${ }^{30}$. W takiej sytuacji ,techniczne" funkcje niemczyzny w nomenklaturze wojskowej zaczęły być coraz częściej oceniane w kontekście narodowościowym. Echa zaostrzającego się konfliktu polsko-niemieckiego w Prusach sprawiły, że na terenie Galicji dotychczasowa tożsamość „cesarska” weszła w stan permanentnego kryzysu.

Jej miejsce zajęła w dużym stopniu mieszana tożsamość polsko-cesarska, względnie ukraińsko-cesarska, będąca zbiorem dwóch postaw: partykularnej - narodowej oraz wspólnej - lojalistycznej i prohabsburskiej. O jej symptomach donosiła między innymi prasa niemiecka na Śląsku austriackim podczas zamieszek polsko-niemieckich i czesko-niemieckich na tym obszarze latem 1914 roku. Wówczas to

28 J.S. Bystroń, op. cit., s. 328 .

29 Poglądy tego środowiska (ostatecznie ukształtowanego dopiero w okresie międzywojennym) z jednoznacznie niemiecko-nacjonalistycznego punktu widzenia prezentował m.in. W. Czermak, In deinem Lager war Österreich. Die österreichisch-ungarische Armee wie man sie nicht kennt, Breslau 1938, s. 21-25.

30 M. Baczkowski, Pod czarno-żóttymi sztandarami. Galicja i jej mieszkańcy wobec austro-węgierskich struktur militarnych 1868-1914, Kraków 2003, s. 355-357. 
polskojęzyczni poborowi mieli jednoznacznie stanąć po stronie polskich, a następnie czeskich demonstrantów, solidaryzując się z nimi na gruncie narodowym przeciw niemieckim nacjonalistom. W żaden sposób natomiast żołnierze ci nie występowali przeciw państwu austro-węgierskiemu ${ }^{31}$. Zmiana tożsamościowa wojskowych z Galicji w pełni uwidoczniła się podczas mobilizacji latem 1914 roku, gdy polski rekrut szedł do wojska habsburskiego z jednej strony bić się o bliżej nieokreśloną Polskę, z drugiej zaś strony walczyć za cesarza i austro-węgierską ojczyznę ${ }^{32}$.

Mobilizacja 1914 roku była ostatnią manifestacją tożsamości „cesarskiej” w środowisku galicyjskich żołnierzy. Kolejne klęski ponoszone na frontach, represje władz austriackich wobec ludności cywilnej oraz gwałtownie pogarszająca się sytuacja aprowizacyjna armii powodowały szybki zanik postawy „cesarskiej” wśród poborowych i rezerwistów ${ }^{33}$. Mundur i coraz uboższa miska strawy przestały odgrywać dotychczasową rolę. Decydujący wpływ na zachodzące zmiany wywarła w tym wypadku przedłużająca się wojna, która pociągnęła za sobą upadek autorytetu państwa i samej instytucji cesarza. Zmieniła się także sama armia. Nabrała ona teraz naprawdę masowego charakteru, z dominującą rolą oficerów rezerwy, szeregowych rezerwistów oraz rekrutów z najnowszych poborów. Wojsko to szybko traciło swój kosmopolityczny, cesarski charakter. Narodowościowe konflikty, tak charakterystyczne dla monarchii naddunajskiej początku XX wieku, nie oszczędziły teraz także sił zbrojnych. Narastały wzajemne oskarżenia - szczególnie chętnie wysuwane pod adresem Słowian i Rumunów - o nielojalność, a wręcz zdradę państwa. Co istotne, ich autorami byli zazwyczaj niemieckojęzyczni oficerowie i politycy, którzy w ten sposób usiłowali wytłumaczyć własne klęski, a zarazem wzmocnić żywioł germański w państwie. Było to całkowitym zaprzeczeniem idei i tożsamości „cesarskiej”, które kładły przecież szczególny nacisk na ponadnarodowy charakter sił zbrojnych i separację wojskowych od problemów świata cywilnego. W chwili rozpadu państwa i jego armii jesienią 1918 roku tożsamość „cesarska” już całkowicie ustąpiła różnorakim aspiracjom społecznym, narodowościowym i niepodległościowym wielojęzycznej masy oficerów i szeregowców ${ }^{34}$. Błędem byłoby jednak sądzić, że to dopiero wielka wojna doprowadziła do zakwestionowania „cesarskiej” tożsamości. I wojna

31 „Ilustrowany Kurier Codzienny” 1914, nr 155, 165; „Silesia” 1914, nr 147.

32 Szerzej zob.: M.J. Olszewska, Człowiek w świecie Wielkiej Wojny. Literatura polska z lat 19141919 wobec I wojny światowej. Wybrane zagadnienia, Warszawa 2004; J. Rozmus, Żotnierskie narracje o wojnie światowej 1914-1918. Strzelcy, legioniści, Polacy w armii austro-węgierskiej, Kraków 2014 oraz A. Krasicki, Dziennik z kampanii rosyjskiej 1914-1916, Warszawa 1988; S. Kawczak, Milknace echa. Wspomnienia z wojny 1914-1920, Warszawa 1991.

33 Szerzej o zmianie postrzegania państwa i upadku tożsamości „cesarskiej” w Galicji, zob.: Stan świadomości narodowej Polaków w przededniu niepodległości, red. J. Machnik, W. Rojek, Kraków 2010; P. Szlanta, „Pod gasnąca gwiazda Habsburgów”. Doświadczenie frontu wschodniego polskich żolnierzy ck armii [w:] Front wschodni I wojny światowej. Studia z dziejów militarnych i polityczno-spotecznych, red. M. Baczkowski, K. Ruszała, Kraków 2013, s. 79-93; R. Plaschka, H. Haselsteiner, A. Suppan, Innere Front. Militärassistenz, Widerstand und Umsturz in der Donaumonarchie 1918, Bd. 1, Wien 1974, s. 182, 299-315; Bd. 2, s. 60, 65-70, 90.

34 H. Brodowska, Chłopi o sobie i Polsce, Warszawa 1984, s. 136-137, 203-209; J.S. Bystroń, op. cit., s. 332. 
światowa jedynie w dramatyczny sposób przyspieszyła procesy samoidentyfikacji, nurtujące c.k. wojskowość od drugiej połowy XIX wieku.

$\mathrm{Na}$ koniec można wreszcie zadać pytanie, na ile „cesarska” tożsamość wojskowych była autentyczna, a w jakim stopniu pozostawała koniunkturalną postawą oficerów i żołnierzy, usiłujących się dopasować do idei obowiązujących w armii habsburskiej. W jakimś stopniu problem ten zweryfikowany został w 1918 roku. Wraz z upadkiem monarchii przestała istnieć i tożsamość „,cesarska”. Oficerowie dawnej c.k. armii zgłaszali swój akces do sił zbrojnych państw-sukcesorów powstałych po upadku Austro-Węgier. Dla wielu austro-węgierskich oficerów niemieckojęzycznych rozpad monarchii stał się pretekstem do zademonstrowania swojej wielkoniemieckiej tożsamości. Większość zawodowych wojskowych wywodzących się z Galicji zgłosiła swój akces do wojska polskiego, bardzo nieliczni wybrali w 1918 roku opcję ukraińską. Tożsamość „cesarska”, po rozpadzie monarchii i abdykacji Karola I, została zepchnięta na zupełny margines i wyeliminowana z publicznego dyskursu. Jej ostatni wyznawcy znaleźli się poza głównym nurtem życia narodowego i politycznego państw sukcesyjnych, powstałych na gruzach monarchii habsburskiej.

\section{BIBLIOGRAFIA}

\section{I. Źródła}

\section{1. Źródła archiwalne}

Österreichisches Staatsarchiv/Kriegsarchiv w Wiedniu (KA):

Kriegsminister Lacy Akten (KLA), 1774, nr 5/1

Alte Feldakten (AFA), Galizien 1846, karton 1805

Ministerium für Landesverteidigung (MLV), Präsidialakten, Sprachen 1908-1914, karton nr 967

Militärische Nachlässe (NL):

B/608 (Rudolf Biedermann)

B/691 (Emil Ratzenhofer)

B/862 (Adolf Stillfried)

\section{Pamiętniki, wspomnienia, korespondencja}

Bojko J., Dwie dusze, Warszawa 1949.

Daszyński I., Pamiętniki, t. 1, Warszawa 1957.

[Goszczyński S.], Seweryn Goszczyński w Galicji. Nieznane pamiętniki, listy i utwory, 1832-1842, wyd. Z. Wasilewski, Lwów 1910.

Haller J., Pamiętniki, Londyn 1966.

Kawczak S., Milknace echa. Wspomnienia z wojny 1914-1920, Warszawa 1991.

Kossak W., Wspomnienia, Warszawa 1973.

Krasicki A., Dziennik z kampanii rosyjskiej 1914-1916, Warszawa 1988. 
Liebermann H., Pamiętniki, Warszawa 1996.

Łańcucki S., Wspomnienia, Warszawa 1957.

Orłowicz M., Moje wspomnienia turystyczne, Wrocław 1970.

Romer J., Pamiętniki, Lwów 1938.

Wiesiołowski F., Pamiętnik z r. 1845-1846, Lwów 1868.

Witos W., Moje wspomnienia, Olsztyn 1981.

Żaba R., Wspomnienia z lat ubiegtych, Kraków 2009.

\section{Prasa}

„Ilustrowany Kurier Codzienny” (Kraków) 1914.

„Militär-Statistisches Jahrbuch” (Wien) 1873-1911.

„Silesia” (Teschen) 1914.

\section{Opracowania}

Allmayer-Beck J.Ch., Die bewaffnete Macht in Staat und Gesellschaft [w:] Die Habsburgermonarchie 1848-1918, Bd. 5: Die bewaffnete Macht, Hg. A. Wandruszka, P. Urbanitsch, Wien 1987.

Allmayer-Beck J.Ch., Lessing E., Die k. (u.) k. Armee 1848-1918, Wien 1974.

Auffenberg-Komarów M., Aus Österreich-Ungarns Teilnahme am Weltkriege, BerlinWien 1920.

Baczkowski M., In Treue zu Kaiser und Vaterland - Galizische Juden im Militär der Habsburger, ,Jahrbuch des Simon-Dubnow-Instituts” XII, 2013, s. 127-149.

Baczkowski M., Pod czarno-żóttymi sztandarami. Galicja i jej mieszkańcy wobec austro-węgierskich struktur militarnych 1868-1914, Kraków 2003.

Brodowska H., Chłopi o sobie i Polsce, Warszawa 1984.

Bystroń J.S., Kultura ludowa, Warszawa 1947.

Czermak W., In deinem Lager war Österreich. Die österreichisch-ungarische Armee wie man sie nicht kennt, Breslau 1938.

Danzer A., Unter der Fahnen. Die Völker Österreich-Ungarns in Waffen, Wien 1889.

Deák I., Der k. (u.) k. Offizier, Wien 1991.

Geschichte des k. und k. Infanterie-Regiments Erzherzog Ludwig Salvator Nr. 58, Wien 1904.

Glückmann K., Das Heerwesen der österreichisch-ungarischen Monarchie, Wien 1911.

Grillparzer F., Sämtliche Werke, Bd. 1, München 1960.

Grodziski S., Historia ustroju społeczno-gospodarczego Galicji 1772-1848, Wrocław 1971.

Historia państwa i prawa Polski, t. 4: Od uwłaszczenia do odrodzenia państwa, red. K. Grzybowski, Warszawa 1982.

Janota R., Geschichte des k. und k. Infanterie Regiments Graf Daun Nr. 56, Teschen 1889.

Kieniewicz S., Konspiracje galicyjskie (1831-1845), Warszawa 1950.

Kotasek E., Graf Lacy. Ein Leben für Österreichs Heer, Horn 1956.

Kozłowski E., Legion Polski na Wegrzech 1848-1849, Warszawa 1883.

Louis-Wawel J., Kronika Rewolucji Krakowskiej w roku 1846, Kraków 1898.

Olszewska M.J., Człowiek w świecie Wielkiej Wojny. Literatura polska z lat 1914-1919 wobec I wojny światowej. Wybrane zagadnienia, Warszawa 2004. 
Österreich-Ungarns letzter Krieg 1914-1918, Hrsg. E. Glaise-Horstenau, Bd. 1, Wien 1930.

Plaschka R.G., Haselsteiner H., Suppan A., Innere Front. Militärassistenz, Widerstand und Umsturz in der Donaumonarchie 1918, Bd. 1-2, Wien 1974.

Prochazká W., Geschichte des k. k. Infanterie Regimentes FML Wilhelm Freiherr von Rheinländer Nr. 24, Wien 1886.

Purschka F. von, Rückblicke auf die Entwicklung des $k$. und $k$. österreichischen Heeres, Lemberg 1892.

Rewolucja czy praca organiczna drogami do niepodległości? W 150. rocznicę wydarzeń 1846 r., red. M. Drozdowski, Poznań 1997.

Rothenberg G., The Army of Francis Joseph, West Lafayette 1998.

Rozmus J., Żotnierskie narracje o wojnie światowej 1914-1918. Strzelcy, legioniści, Polacy $w$ armii austro-węgierskiej, Kraków 2014.

Rydel J., W stużbie cesarza i króla. Generałowie i admirałowie narodowości polskiej w sitach zbrojnych Austro-Węier w latach 1868-1918, Kraków 2001.

Schmidt-Brentano A., Die Armee in Österreich. Militär, Staat und Gesellschaft 1848 1867, Boppard am Rhein 1975.

Stan świadomości narodowej Polaków w przededniu niepodległości, red. J. Machnik, W. Rojek, Kraków 2010.

Szlanta P., „Pod gasnaca gwiazda Habsburgów”. Doświadczenie frontu wschodniego polskich żotnierzy ck armii [w:] Front wschodni I wojny światowej. Studia z dziejów militarnych i polityczno-społecznych, red. M. Baczkowski, K. Ruszała, Kraków 2013, s. 9-93.

Szuro S., Reforma wojskowa przeprowadzona w państwie austro-węgierskim w 1868 r. i jej realizacja ze szczególnym uwzględnieniem Galicji, „Studia i Materiały do Historii Wojskowości" 1990, t. 33, s. 205-241.

Wagner W., Die k. u. k. Armee - Gliederung und Aufgabestellung [w:] Die Habsburgermonarchie 1848-1918, Bd. 5: Die bewaffnete Macht, Hg. A. Wandruszka, P. Urbanitsch, Wien 1987.

Wrede A. von, Geschichte der k. und k. Wehrmacht, Bd. 1-5, Wien 1898-1903.

Żychowski M., Rok 1846 w Rzeczypospolitej Krakowskiej i Galicji, Warszawa 1956. 